FACTA UNIVERSITATIS

Series: Physical Education and Sport Vol. 16, N 1, 2018, pp. 95 - 106

https://doi.org/10.22190/FUPES171231009P

Review article

\title{
INFLUENCE OF MORPHOLOGICAL CHARACTERISTICS ON RUNNING PERFORMANCE OF ENDURANCE ATHLETES
}

\author{
UDC 796.012:61 \\ 796.422 .16
}

\author{
Ivana Petrovic $^{1}$, Marjan Marinkovic ${ }^{2}$ \\ ${ }^{1}$ Faculty of Sport and Physical Education, University of Niš, Serbia \\ ${ }^{2}$ Military Academy, University of Defense, Ministry of Defense, Belgrade, Serbia
}

\begin{abstract}
Running is a popular form of physical activity and can be carried out through several different distances. Morphological characteristics, such as skin fold thickness, limb girth and length, body weight and body fat percentage have an impact on endurance running. The objective of this systematic review study is to collect and analyze studies about the influence of morphological characteristics on running performance of endurance athletes. Based on an analysis of electronic databases and the inclusion criteria set, 20 studies were included in the analysis. The length of the extremities and the sum of the skin folds thickness have the highest statistical significance as the predictor. The results of the analyzed studies indicate that slim limbs, longer legs, lower total skin fold thickness and lower body fat percentage are some of the characteristics that can be good predictors for competitive success and a model to be tended during the preparation period of male and female endurance runners.
\end{abstract}

Key words: anthropometry, body composition, endurance, running.

\section{INTRODUCTION}

Running is a popular form of physical activity and can be carried out through several different distances (Marti, Abelin, \& Minder, 1988; Nettleton, \& Hardey, 2006). Many physiological, anthropometric and training characteristics are related to racing performance, depending on the length and duration of the activity (Anderson, 1996; Morgan, Martin, \& Krahenbuhl, 1989; Saunders, Pyne, Telford, \& Hawley, 2004). The achieved result in medium- and long-distance running depends on several variables such as physiological characteristics (Saunders et al., 2004), genetics and demographic characteristics (Onywera,

Received December 31, 2017 / Accepted April 16, 2018

Corresponding author: Ivana Petrović

Faculty of Sport and Physical Education, University of Niš, St. Čarnojevića 10a, 18000 Niš, Serbia

Phone: +381 18510900 •E-mail: ivanica.petrovic@yahoo.com 
2009), physiological parameters (Pate, \& O'Neill, 2007; Williams, \& Neptune, 1983), age (Lepers, \& Cattagni, 2012), gender (Pate, \& O'Neill, 2007), training (Karp, 2007; Davis et al., 2001), previous experience (Herbst, 2011), anthropometric characteristics (Hagan, Smith, \& Gettman, 1981; Rüst, Knechtle, Knechtle, Wirth, \& Rosemann, 2012) and body composition (Arrese, \& Ostariz, 2006).

Morphological characteristics, such as skin fold thickness, limb girth and length, body weight and body fat percentage have an impact on running (Knechtle, Stiefel, Rosemann, Rust, \& Zingg, 2015). The assessment of body composition gives an insight into fat and lean mass in the human body. It is necessary to respect minimum values for normal functioning of the body. For example, the percentage of essential fat in women is $8-12 \%$ of total body fat mass, while in men it ranges from 3-5\% of total body fat mass recommended by the National Academy of Sports Medicine (NASM) (Muth, 2009). Determination of body composition or percentage of body fat is a key factor in the assessment of body health (Fahey, Insel, \& Roth, 2001; Gilliat-Wimberly, Manore, Woolf, Swan, \& Carroll, 2001), but it is also useful in monitoring potential effects of the training process and health status of young athletes (Hergenroeder, \& Klish, 1990; Claessens, Hlatky, Lefevre, \& Holdhaus, 1994). For example, runners with a proportionally smaller amount of body mass concentrated in the extremities, particularly in the legs, would perform less work moving their body segments during running if all the other factors are unchanged. Therefore, leg mass and distribution of leg mass might be important characteristics of distance runners' performance (Myers, \& Steudel, 1985). On the other hand, in previous research, it has been shown that in addition to the body composition values, runners are influenced by several anthropometric parameters such as body height (Bale, Bradbury, \& Colley, 1986; Maldonado, Mujika, \& Padilla, 2002), arm circumference (Tanaka, \& Matsuura, 1982), total skin fold thickness (Bale et al., 1986; Arrese, \& Ostariz, 2006) and different lower limb skin fold and circumferences (Legaz, \& Eston, 2005). Arrese and Ostariz (2006) found a high positive correlation between the skin fold thickness of lower extremities and the speed of running in disciplines from sprinting to middle- and long-distance running. Considering anthropometric characteristics, taller runners seemed to run slower than shorter ones (Zillmann et al., 2013).

These morphological data can be good predictors for selection, training process planning and improving running results. A small number of studies were concerned with the effects of some other components, such as the amount of skeletal muscle mass, total body water and bone mass. Based on the above mentioned, the aim of this review study was to collect and analyze studies on the influence of morphological characteristics on running performance of endurance athletes.

\section{METHODS}

\section{Search strategy}

In order to access relevant studies, the following electronic databases were searched: Google Scholar, Kobson and PubMeb. The research was limited to using the following keywords related to the problem of this review paper: anthropometry, body composition, endurance running and track and field running. Within the electronic databases, advanced research was used as well as the option for searching keywords only in titles, abstracts or abstract keywords. 


\section{Selection of the research and qualification criteria}

The final analysis included all the studies published in the last 12 years, namely between 2005 and 2017, whose samples belong to the group of endurance runners who have been part of some training process for at least a year and which applied parameters for determining body components and parameters for determining morphological characteristics.

\section{Data analysis}

Table 1 provides an overview of close analyses of the 20 studies which satisfied the set criteria. Following the conventions for systematic reviews, the table presents the following parameters: information on the sample of participants (the number of participants, gender and age), morphological characteristics, study design, results and conclusion.

Table 1 Summary of the characteristics of all studies meeting the inclusion criteria

\begin{tabular}{|c|c|c|c|c|c|}
\hline Ref. & $\begin{array}{l}\text { Sample (gender. } \\
\text { number and age) }\end{array}$ & $\begin{array}{l}\text { Morphological } \\
\text { characteristics }\end{array}$ & Study design & $\begin{array}{c}\text { Results } \\
(\mathrm{M} \pm \mathrm{S} . \mathrm{D})\end{array}$ & Conclusion \\
\hline $\begin{array}{l}\text { Legaz \& } \\
\text { Eston } \\
\text { (2005) }\end{array}$ & $\begin{array}{l}\mathrm{M}: 24 \\
\mathrm{~F}: 13\end{array}$ & $\begin{array}{l}\sum 6 \mathrm{SF}: 44.2 \pm 10.8 ; \\
42.1 \pm 9.2 ; \\
42.2 \pm 10.2 ; \\
41.7 \pm 10.2 \\
\text { (initional, after } \\
\text { 1., 2., 3. year) }\end{array}$ & $\begin{array}{l}\sum 6 \mathrm{SF} \text { and the best } \\
\text { running } \\
\text { performance were } \\
\text { recorded at the } \\
\text { beginning and } \\
\text { after one, two, } \\
\text { and three years of } \\
\text { training in short, } \\
\text { middle and long } \\
\text { distance runners. }\end{array}$ & $\begin{array}{l}\text { IAAF } F_{\text {trough }} \\
\text { years } \uparrow \\
\sum 6 \mathrm{SF}_{\text {trough }} \\
\text { years } \downarrow \\
(\mathrm{p}<.05)\end{array}$ & $\begin{array}{l}\text { The lower limb } \\
\text { skinfolds may } \\
\text { be particularly } \\
\text { useful } \\
\text { predictors of } \\
\text { running } \\
\text { performance. }\end{array}$ \\
\hline $\begin{array}{l}\text { Vučetić } \\
\text { et } \\
\text { al. (2005) }\end{array}$ & 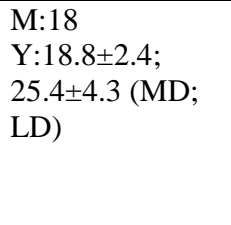 & \%BF: $7.1 ; 5.3$ & $\begin{array}{l}\text { Morphological } \\
\text { characteristics and } \\
\text { the difference } \\
\text { between the athletes } \\
\text { of various running } \\
\text { events. }\end{array}$ & $\begin{array}{l}\text { LD runners } \\
\text { Sig. } \uparrow \text { lower } \\
\text { circum. of } \\
\text { the thigh } \\
\text { and lower } \\
\text { leg }\end{array}$ & $\begin{array}{l}\text { The upper arm } \\
\text { skinfold is } \\
\text { Sig. } \uparrow \text { in } \\
\text { middle- } \\
\text { distance } \\
\text { runners. }\end{array}$ \\
\hline $\begin{array}{l}\text { Arrese \& } \\
\text { Ostariz } \\
\text { (2006) }\end{array}$ & $\begin{array}{l}\text { M: } 83 \\
F: 37 \\
Y: 21.83 \pm 3.34 \\
30.94 \pm 4.26 \\
\text { (MD; LD) }\end{array}$ & $\begin{array}{l}\sum S F: 37.75 \pm 4.88 ; \\
33.19 \pm 5.54(\mathrm{MD} ; \\
\left.\mathrm{LD}_{\text {male }}\right) \\
54.30 \pm 12.38 ; \\
44.41 \pm 7.70(\mathrm{MD} ; \\
\left.\mathrm{LD}_{\text {fimale }}\right)\end{array}$ & $\begin{array}{l}\text { Correlation between } \\
\sum 6 \mathrm{SF} \text { and } \\
\text { competitive running } \\
\text { performance in } \\
\text { middle and long } \\
\text { distance male and } \\
\text { female elite runners. }\end{array}$ & $\begin{array}{l}\text { Positive } \\
\text { corr. btw } \\
\text { front thigh, } \\
\text { medial calf } \\
\mathrm{SF}, \\
1,5 \mathrm{~km} \text { run } \\
\text { (p<.05) } \\
\text { Positive } \\
\text { corr. btw } \\
\text { front thigh, } \\
\text { medial calf } \\
\mathrm{SF} 10 \mathrm{~km} \\
\text { run }(\mathrm{p}<.05)\end{array}$ & $\begin{array}{l}\text { SF thicknesses } \\
\text { in the lower } \\
\text { limb are } \\
\text { positively } \\
\text { associated with } \\
\text { running time } \\
\text { over several } \\
\text { distances. }\end{array}$ \\
\hline
\end{tabular}




\begin{tabular}{|c|c|c|c|c|c|}
\hline Ref. & $\begin{array}{l}\text { Sample (gender. } \\
\text { number and age) }\end{array}$ & $\begin{array}{l}\text { Morphological } \\
\text { characteristics }\end{array}$ & Study design & $\begin{array}{c}\text { Results } \\
(\mathrm{M} \pm \text { S.D })\end{array}$ & Conclusion \\
\hline $\begin{array}{l}\text { Hoffman } \\
(2008)\end{array}$ & $\begin{array}{l}\text { M:310 } \\
F: 82 \\
Y: 18-60+\end{array}$ & $\begin{array}{l}\text { BMI: } \\
23.2 ; 20.6 \\
(\mathrm{M} ; \mathrm{F})\end{array}$ & $\begin{array}{l}\text { Physical } \\
\text { characteristics and } \\
\text { competitive running } \\
\text { performance in } \\
\text { ultra-marathon } \\
\text { runners. }\end{array}$ & $\begin{array}{l}\text { Average } \\
\text { running } \\
\text { speed and } \\
\text { BMI were } \\
\text { negatively } \\
\text { correlated } \\
\text { for both } \\
\text { men } \\
(p<0.01) \\
\text { and women } \\
(p=0.02)\end{array}$ & $\begin{array}{l}\text { Lower BMI } \\
\text { values were } \\
\text { associated with } \\
\text { faster running } \\
\text { times. }\end{array}$ \\
\hline $\begin{array}{l}\text { Knechtle } \\
\text { et al. } \\
(2008)\end{array}$ & $\begin{array}{l}\text { M:19 } \\
\mathrm{Y}: 46.2 \pm 9.6\end{array}$ & $\begin{array}{l}\text { BMI: } 22.5 \pm 1.9 \\
\text { \%BF: } 13.1 \pm 3.3\end{array}$ & $\begin{array}{l}\text { Association of } \\
\text { anthropometric } \\
\text { parameters to race } \\
\text { performance in } \\
\text { ultra-endurance } \\
\text { runners. }\end{array}$ & $\begin{array}{l}\text { Positive } \\
\text { correlation } \\
\text { of upper } \\
\text { arm } \\
\text { circumferen } \\
\text { ce with the } \\
\text { total } \\
\text { running } \\
\text { time } \\
(\mathrm{p}<0.05)\end{array}$ & $\begin{array}{l}\text { Circumfer. of } \\
\text { the upper arm } \\
\text { was the only } \\
\text { factor } \\
\text { associated with } \\
\text { performance in } \\
\text { well- } \\
\text { experienced } \\
\text { ultra marathon } \\
\text { runners. }\end{array}$ \\
\hline $\begin{array}{l}\text { Vučetić } \\
\text { et al. } \\
\text { (2008) }\end{array}$ & $\begin{array}{l}\mathrm{M}: 23 \\
\mathrm{Y}: 18.6 \pm 2.4 \\
27.2 \pm 4.7(\mathrm{MD} ; \\
\mathrm{LD})\end{array}$ & $\begin{array}{l}\text { BMI: } \\
21.2 \pm 1.7 ; \\
21.5 \pm 1.4 \\
\% \text { BF: } \\
6.9 \pm 2.7 ; 6.0 \pm 1.6\end{array}$ & $\begin{array}{l}\text { Morphological } \\
\text { characteristics and } \\
\text { the difference } \\
\text { between the athletes } \\
\text { of various running } \\
\text { events. }\end{array}$ & $\begin{array}{l}\text { Greater } \\
\text { upper arm } \\
\text { skin fold } \\
\text { and lower } \\
\text { upper arm } \\
\text { circumferen } \\
\text { ce in MD } \\
\text { (p<.01) and } \\
\text { lower limb } \\
\text { and calf } \\
\text { circumferen } \\
\text { ces in LD } \\
(p<.05) .\end{array}$ & $\begin{array}{l}\text { Morph. } \\
\text { character. that } \\
\text { affect running } \\
\text { success are } \\
\text { different in } \\
\text { middle- and } \\
\text { long-distance } \\
\text { runners. }\end{array}$ \\
\hline $\begin{array}{l}\text { Kong \& } \\
\text { Heer } \\
(2008)\end{array}$ & $\begin{array}{l}\text { M:5 } \\
Y: 22.0 \pm 1.8\end{array}$ & $\begin{array}{l}\text { BMI: } 20.1 \pm 1.8 \\
\% \text { BF: } 5.3 \pm 1.6 \\
\text { Calf cc: } \\
34.5 \pm 2.3 \mathrm{~cm}\end{array}$ & $\begin{array}{l}\text { Anthropometric, } \\
\text { gait and lower } \\
\text { extremity strength } \\
\text { characteristics of six } \\
\text { elite Kenyan } \\
\text { distance runners } \\
\text { were analyzed to } \\
\text { understand their } \\
\text { success. }\end{array}$ & $\begin{array}{l}\text { Low BMI, } \\
\% \text { BF and } \\
\text { small calf } \\
\text { circumferen } \\
\text { ce. }\end{array}$ & $\begin{array}{l}\text { Their slim } \\
\text { limbs may } \\
\text { positively } \\
\text { contribute to } \\
\text { performance } \\
\text { by having a } \\
\text { low moment of } \\
\text { inertia and } \\
\text { requiring less } \\
\text { muscular effort } \\
\text { in leg }\end{array}$ \\
\hline
\end{tabular}




\begin{tabular}{|c|c|c|c|c|c|}
\hline Ref. & $\begin{array}{l}\text { Sample (gender. } \\
\text { number and age) }\end{array}$ & $\begin{array}{l}\text { Morphological } \\
\text { characteristics }\end{array}$ & Study design & $\begin{array}{c}\text { Results } \\
(\mathrm{M} \pm \text { S.D })\end{array}$ & Conclusion \\
\hline $\begin{array}{l}\text { Knechtle } \\
\text { et } \\
\text { al. (2009) }\end{array}$ & $\begin{array}{l}\mathrm{M}: 15 \\
\mathrm{Y}: 46.7 \pm 5.8\end{array}$ & $\begin{array}{l}\text { BMI:23.1 } 1 \pm 1.84 \\
\% \text { BF: } 14.4 \pm 3.5\end{array}$ & $\begin{array}{l}\text { The influence of } \\
\text { anthropometric and } \\
\text { training parameters } \\
\text { on race performance } \\
\text { in ultra-endurance } \\
\text { runners. }\end{array}$ & $\begin{array}{l}\text { Sig. in } \\
\text { height, tight } \\
\text { and } \\
\text { suprailiac \& } \\
\text { calf } \\
\mathrm{SF}(\mathrm{p}<.05) \\
\text { and leg } \\
\text { length, } \\
\text { upper arm } \\
\text { cc }(\mathrm{p}=.00) \\
\text { with total } \\
\text { race time. }\end{array}$ & $\begin{array}{l}\text { Anthrop. and } \\
\text { training } \\
\text { volume does } \\
\text { not seem to } \\
\text { have a major } \\
\text { effect on race } \\
\text { performance in } \\
\text { a } 24-\text { h run. }\end{array}$ \\
\hline
\end{tabular}

\begin{tabular}{|c|c|c|}
\hline $\begin{array}{l}\text { Knechtle } \\
\text { et }\end{array}$ & $\begin{array}{l}\text { M:17 } \\
Y: 41.2 \pm 6.6\end{array}$ & $\begin{array}{l}\text { BMI: } 22.4 \pm 1.2 \\
\% \text { BF: } 12.9 \pm 1.5\end{array}$ \\
\hline al. (2009) & & \\
\hline
\end{tabular}

Association of

anthropometric

parameters with

race performance

ultra marathon

runners.

$\begin{array}{ll}\text { Positive } & \text { Body mass and } \\ \text { association } & \text { upper arm } \\ \text { between } & \text { circum. were } \\ \text { total } & \text { negatively } \\ \text { running } & \text { associated with } \\ \text { time and } & \text { race } \\ \text { body mass } & \text { performance in } \\ \text { ( }<<.05) & \text { well } \\ \text { and upper } & \text { experienced } \\ \text { arm } & \text { ultra marathon } \\ \text { circumfer. } & \text { runners } \\ (\mathrm{p}<.05) & \end{array}$

BMI: $22.9 \pm 1.8 \quad$ Association of skin- Sig. $\uparrow$

association fold

\begin{tabular}{lll}
\hline Knechtle & M:25 & BMI: $22.9 \pm 1.8$ \\
$\&$ & Y:44.5 \pm 7.0 & \%BF: $13.1 \pm 3.2$ \\
Roseman & & \\
n (2009) & &
\end{tabular}

fold thicknesses

with total race time

in mountain ultra-

calf SF with small to

marathoners.

total race

time $(\mathrm{p}<$ association

$0.05)$

with total race

time.

\begin{tabular}{llll}
\hline Hoffman & M:75 & BMI: & \\
at & F:34 & $24.8 \pm 2.7 ;$ & \\
al. (2010) & Y:16-67 & $21.2 \pm 2.1$ & \\
& & $\%$ BF: & pert \\
& & $17 \pm 5 \cdot 21 \pm 6$
\end{tabular}

Association of body Sig. $\uparrow$ corr. The faster men

composition $\quad(\mathrm{p}=.0025)$ have lower

characteristics with between percent body

performance among percent fat values than

participants in a body fat and the slower

$161-\mathrm{km}$ trail ultra finish time men, and

marathon.

for men. finishers have

$\% \mathrm{BF} \downarrow$ in lower percent

finishers vs body fat values

non- than non-

finishers for finishers.

men

$(\mathrm{p}=.03)$,

women

$(\mathrm{p}=.04)$. 


\begin{tabular}{|c|c|c|c|c|c|}
\hline Ref. & $\begin{array}{l}\text { Sample (gender. } \\
\text { number and age) }\end{array}$ & $\begin{array}{l}\text { Morphological } \\
\text { characteristics }\end{array}$ & Study design & $\begin{array}{c}\text { Results } \\
(\mathrm{M} \pm \text { S.D })\end{array}$ & Conclusion \\
\hline $\begin{array}{l}\text { Knechtle } \\
\text { et } \\
\text { al. (2011) }\end{array}$ & $\begin{array}{l}\mathrm{F}: 42 \\
\mathrm{Y}: 38.5 \pm 1.4\end{array}$ & $\begin{array}{l}\text { BMI: } 21.2 \pm 0.3 \\
\% \text { BF: } 27.2 \pm 0.8\end{array}$ & $\begin{array}{l}\text { Anthropometric and } \\
\text { training variables } \\
\text { related to half- } \\
\text { marathon running } \\
\text { performance. }\end{array}$ & $\begin{array}{l}\text { BW; BMI; } \\
\% \text { BF and SF } \\
\text { thickness } \\
\text { Sig. } \uparrow \\
\text { correlate } \\
\text { w/race time. }\end{array}$ & $\begin{array}{l}\text { Anthrop. and } \\
\text { training relate } \\
\text { to } \\
\text { halfmarathon } \\
\text { race time, and } \\
\text { skin } \\
\text { thicknesses } \\
\text { associated with } \\
\text { running speed } \\
\text { during } \\
\text { training. }\end{array}$ \\
\hline $\begin{array}{l}\text { Barandun } \\
\text { et } \\
\text { al. (2012) }\end{array}$ & $\begin{array}{l}\text { M:126 } \\
\text { Y: } \\
42.8 \pm 10.8\end{array}$ & $\begin{array}{l}\text { BMI: } 23.4 \pm 2.2 \\
\% \text { BF: } 16.3 \pm 5.6\end{array}$ & $\begin{array}{l}\text { Association of } \\
\text { anthropometric and } \\
\text { training } \\
\text { characteristics with } \\
\text { race times in } \\
\text { marathon runners. }\end{array}$ & $\begin{array}{l}\text { Pectoral } \\
(\mathrm{p}<.0001) \\
\text { Mid axilla } \\
(\mathrm{p}<.0001) \\
\text { Abdomin. } \\
(\mathrm{p}<.0001) \\
\text { Medial calf } \\
(\mathrm{p}<.0001) \\
\sum 7 \mathrm{SF} \\
(\mathrm{p}<.0001)\end{array}$ & $\begin{array}{l}\text { Low body fat } \\
\text { and running } \\
\text { speed during } \\
\text { training are } \\
\text { two key factors } \\
\text { for a fast } \\
\text { marathon race } \\
\text { time in } \\
\text { recreational } \\
\text { male } \\
\text { marathoner } \\
\text { runners. }\end{array}$ \\
\hline $\begin{array}{l}\text { Mooses } \\
\text { et al. } \\
\text { (2013a) }\end{array}$ & $\begin{array}{l}\text { M:45 } \\
\text { Y: } \\
23.0 \pm 4.4 ; 25.5 \\
\pm 8.3 \text { (competit.; } \\
\text { recreation) }\end{array}$ & $\begin{array}{l}\text { BMI: } \\
21.19 \pm 1.05 \\
22.20 \pm 2.05 \\
\% \text { BF: } \\
7.29 \pm 1.62 \\
10.31 \pm 4.49\end{array}$ & $\begin{array}{l}\text { Comparation in } \\
\text { body composition } \\
\text { parameters that are } \\
\text { related to the } \\
\text { individual running } \\
\text { economy measured } \\
\text { on track. }\end{array}$ & $\begin{array}{l}\% \mathrm{BF}, \\
\% \mathrm{BF} \text { calf } \\
\text { and IAAF } \\
\text { sig. } \uparrow \text { in } \\
\text { compet. } \\
(\mathrm{p}<.05)\end{array}$ & $\begin{array}{l}\text { Running } \\
\text { economy at the } \\
\text { first threshold } \\
\text { was not } \\
\text { significantly } \\
\text { related to any } \\
\text { of the } \\
\text { measured body } \\
\text { composition } \\
\text { values or leg } \\
\text { mass ratios } \\
\text { either in the } \\
\text { competitive or } \\
\text { in the } \\
\text { recreational } \\
\text { runners group. }\end{array}$ \\
\hline $\begin{array}{l}\text { Mooses } \\
\text { et al. } \\
\text { (2013b) }\end{array}$ & $\begin{array}{l}\text { M:40 } \\
\text { Y: } \\
21.1 \pm 3.4 \\
25.4 \pm 3.8(\mathrm{MD} ; \\
\mathrm{LD})\end{array}$ & $\begin{array}{l}\text { BMI: } \\
21.6 \pm 1.5 ; \\
21.1 \pm 1.2 \\
\% \text { BF: } \\
8.1 \pm 2.0 ; 7.6 \pm 1.9\end{array}$ & $\begin{array}{l}\text { Association of } \\
\text { anthropometric, } \\
\text { body composition } \\
\text { and physiological } \\
\text { parameters in } \\
\text { middle- and long- } \\
\text { distance runners. }\end{array}$ & $\begin{array}{l}\text { MD } \uparrow \text { lower } \\
\text { leg length } \\
(\mathrm{p}<0.05)\end{array}$ & $\begin{array}{l}\text { Relevance of } \\
\text { specific } \\
\text { anthrop. } \\
\text { parameters } \\
\text { predict middle, } \\
\text { but not long } \\
\text { distance } \\
\text { run perform }\end{array}$ \\
\hline
\end{tabular}




\begin{tabular}{|c|c|c|c|c|c|}
\hline Ref. & $\begin{array}{l}\text { Sample (gender. } \\
\text { number and age) }\end{array}$ & $\begin{array}{c}\text { Morphological } \\
\text { characteristics }\end{array}$ & Study design & $\begin{array}{c}\text { Results } \\
(\mathrm{M} \pm \text { S.D })\end{array}$ & Conclusion \\
\hline $\begin{array}{l}\text { Zillmann } \\
\text { et } \\
\text { al. (2013) }\end{array}$ & $\begin{array}{l}\text { M:173 } \\
\text { Y: } \\
40.2 \pm 10.1 ; \\
42.8 \pm 10.8 \text { (half-; } \\
\text { marathon) }\end{array}$ & $\begin{array}{l}\text { BMI: } \\
23.3 \pm 2.2 \\
23.7 \pm 2.7 \\
\% \text { BF: } \\
17.5 \pm 4.6 \\
16.3 \pm 3.6\end{array}$ & $\begin{array}{l}\text { Comparison of } \\
\text { training and } \\
\text { anthropometric } \\
\text { characteristics } \\
\text { between } \\
\text { recreational male } \\
\text { half-marathoners } \\
\text { and marathoners }\end{array}$ & $\begin{array}{l}\text { HM runners } \\
\text { positive corr. } \\
\text { of BMI,\%BF } \\
\text { with race } \\
\text { time. } \\
\text { M runners } \\
\text { positive } \\
\text { corr. of } \\
\text { \% BF with } \\
\text { race time } \\
(\mathrm{p}<.0001) \text {. }\end{array}$ & $\begin{array}{l}\text { Both groups of } \\
\text { athletes profit } \\
\text { from low body } \\
\text { fat and a high } \\
\text { running speed } \\
\text { during training } \\
\text { for fast race } \\
\text { times. }\end{array}$ \\
\hline $\begin{array}{l}\text { Dellagrana } \\
\text { et } \\
\text { al. (2014) }\end{array}$ & 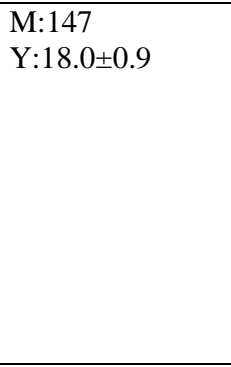 & $\%$ BF: $11.63 \pm 2.87$ & $\begin{array}{l}\text { Association of } \\
\text { physiological, } \\
\text { anthropometric, } \\
\text { strength, and } \\
\text { muscle power } \\
\text { characteristics with } \\
\text { running } \\
\text { performance in } \\
\text { young middle- } \\
\text { distance runners. }\end{array}$ & $\begin{array}{l}\text { SMM } \\
(\mathrm{p}=.005) \\
\mathrm{BH}(\mathrm{p}<.05)\end{array}$ & $\begin{array}{l}\text { Anthropometri } \\
\text { c measures } \\
\text { showed } \\
\text { significant } \\
\text { influence in } \\
\text { performance } \\
\text { prediction. }\end{array}$ \\
\hline $\begin{array}{l}\text { Yang at } \\
\text { al. (2015) }\end{array}$ & $\begin{array}{l}\text { F:96 } \\
\text { Y: } 23.09 \pm 2.74 ; \\
22.45 \pm 2.80 ; \\
19.09 \pm 2.83 \\
\text { (international, } \\
\text { national, } \\
\text { average) }\end{array}$ & 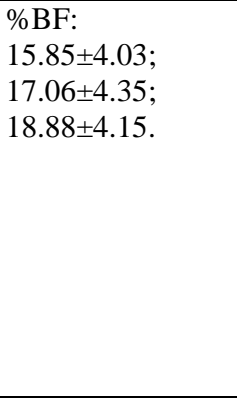 & $\begin{array}{l}\text { Association of } \\
\text { anthropometric, } \\
\text { characteristics with } \\
\text { personal bests of } \\
\text { international, } \\
\text { national and } \\
\text { average levels long- } \\
\text { distance female } \\
\text { runners. }\end{array}$ & $\begin{array}{l}\text { Positive corr. } \\
\text { btw forearm } \\
\text { girth and } \\
\text { PBs, and } \\
\text { subscapula, } \\
\text { abdomen, } \\
\text { Iliac crest } \\
\text { and triceps } \\
\text { SF and PB } \\
\text { for total } \\
\text { athletes. }\end{array}$ & $\begin{array}{l}\text { The } \\
\text { international } \\
\text { and national } \\
\text { runners have } \\
\text { low tights } \\
\text { circumferences } \\
\text {, height, longer } \\
\text { limbs and skin } \\
\text { folds compare } \\
\text { to average one. }\end{array}$ \\
\hline $\begin{array}{l}\text { Gómez- } \\
\text { Molina } \\
\text { (2017) }\end{array}$ & $\begin{array}{l}\text { M:78 } \\
\text { Y: } \\
31.5 \pm 7.2 \\
34.2 \pm 6.8\end{array}$ & $\begin{array}{l}\text { BMI: } \\
22.4 \pm 2.0 \\
23.7 \pm 2.1 \\
\text { SF: } \\
51.5 \pm 17.5 \\
56.9 \pm 24.0\end{array}$ & $\begin{array}{l}\text { Establishing and } \\
\text { validating various } \\
\text { predictive equations } \\
\text { in Male half- } \\
\text { marathon Runners } \\
\text { who participated in } \\
\text { two different phases }\end{array}$ & $\begin{array}{l}\text { Positive } \\
\text { corr. of BM, } \\
\text { BMI, } \sum S F \\
\text { w/the race } \\
\text { result } \\
(\mathrm{p}<.05)\end{array}$ & $\begin{array}{l}\text { The proposed } \\
\text { equations and } \\
\text { their validation } \\
\text { showed a high } \\
\text { prediction of } \\
\text { half-marathon } \\
\text { performance in } \\
\text { long distance } \\
\text { male runners. }\end{array}$ \\
\hline $\begin{array}{l}\text { Šolaja at } \\
\text { al. (2017) }\end{array}$ & $\begin{array}{l}\text { M:5 } \\
F: 4 \\
Y: 22.87 \pm 3.39\end{array}$ & $\begin{array}{l}\text { BMI: } \\
21.74 \pm 1.46 ; \\
20.05 \pm 0.8 \\
\% \text { BF: } 6.94 \pm 0.99 \\
13.98 \pm 2.39 \\
(\mathrm{M} ; \mathrm{F})\end{array}$ & $\begin{array}{l}\text { Assuming } \\
\text { correlation of } \\
\text { various athletics } \\
\text { disciplines with } \\
\text { anthropometric } \\
\text { factors and the } \\
\text { training process. }\end{array}$ & $\begin{array}{l}\text { Positive } \\
\text { correlation of } \\
\text { BH }(\mathrm{p}<.05), \\
\text { BM }(\mathrm{p}=.00), \\
\sum \mathrm{SF}, \mathrm{BMI} \\
\text { and \%BF } \\
\text { (p=.01) } \\
\text { w/running } \\
\text { discipline }\end{array}$ & $\begin{array}{l}\text { It is possible to } \\
\text { increase the } \\
\text { loss of body } \\
\text { fat and } \\
\text { indirectly } \\
\text { improve the } \\
\text { athletic } \\
\text { performance in } \\
\text { athletics. }\end{array}$ \\
\hline
\end{tabular}




\section{RESULTS}

\section{Study selection}

Database searches returned 145 studies. After eliminating all duplicated papers and analyzing titles and abstracts, 25 studies entered the next stage of analysis. Only the studies which included relevant outcomes were considered. The final number of the studies in the analysis was 20 .

\section{Study characteristics}

The first research in this group was published in 2005 (Legaz \& Eston, 2005; Vučetić, Babić, Šentija \& Nekić, 2005), and the last one in 2017 (Gómez-Molina, Ogueta-Alday, Camara, Stickley, Rodríguez- Marroyo, \& García-López, 2017; Šolaja, Milankov, Pejaković, \& Stokić, 2017). The number of participants in the analyzed studies ranged from six, the lowest number of participants in the research of Kong \& De Heer (2008) to 392, and the highest number of participants in the study of Hoffman (2008).

Gender-wise, male groups were presented the most, with six studies including both, males and females, while in the research of Yang, Wang, Bao, \& Hu (2015) the participants were only females. The youngest participant was16 years old (Hoffman, Lebus, Ganong, Casazza, \& Van Loan, 2010), whereas the oldest ones were 60 years and older (Hoffman, 2008).

For the estimation of longitudinal and transversal dimensionality, standardized anthropometric measuring instruments were used, while the anthropometric method was mostly used for estimating body composition content (the sum of skin folds for calculating \% BF by Siri (1961); Heath, \& Carter (1967); Jackson, \& Pollock (1985); Ball, Swan, \& Desimone (2004); Legaz, \& Est (2005); Lucia et al., (2006)), bioelectric impedance (BIA) (Yang et al., 2015; Hoffman et al., 2010) and dual-energy X-ray absorptiometry (DEXA) (Mooses et al., 2013a; 2013b).

\section{DISCUSSION}

Based on the analyzed studies, it is evident that the body height of middle- and longdistance runners ranges from $1.73 \pm 0.05$ to $1.83 \pm 4.17 \mathrm{~m}$ in males, and from $1.60 \pm 0.09$ to $1.69 \pm 5.36 \mathrm{~m}$ in females. These anthropometric measurements are in correlation with other research where, for example, middle- and long-distance male and female runners of the Serbian national team were $1.83 \pm 4.17 \mathrm{~m}$ and $1.69 \pm 5.36 \mathrm{~m}$ tall respectively (Šolaja et al., 2017), whereas Croatian middle- and long-distance runners were $1.80 \pm 5.4 \mathrm{~m}$ and $1.82 \pm 5.2 \mathrm{~m}$ tall respectively (Vučetić, Matković, \& Šentija, 2008). Kenyan distance runners well recognized for their success in distance running were $1.77 \pm 0.06 \mathrm{~m}$ tall (Kong, \& Heer, 2008). Ultra-marathoners' height in the analyzed research ranged between $175 \pm 6$ to $179 \pm 6$ m (Hoffman, 2008; Knechtle, Knechtle, Schulze, \& Kohler, 2008; Knechtle, Wirth, Knechtle, Zimmermann, \& Kohler, 2009). In the research of Ramírez-Vélez, Argothy-Bucheli, Sánchez-Puccini, Meneses-Echávez, \& López-Albán (2015) Colombia's top long-distance runners were $1.71 \mathrm{~m}$ tall on average, which is below average in the analyzed studies. In the research of Yang et al. (2015) international and national top level long-distance female runners were $1.61 \mathrm{~m}$ tall, amateurs were $1.65 \pm 5.08 \mathrm{~m}$ tall, $1.66 \pm 0.009 \mathrm{~m}$ in the research of Knechtle, Knechtle, Barandun, and 
Rosemann (2011), while ultra-marathoners ranged between $161 \pm 7 \mathrm{~m}$ to $1.66 \pm 8 \mathrm{~m}$ (Hoffman, 2008). Based on the previous studies, with gradual decrease in running distance from marathon to $400 \mathrm{~m}$, the average body height of runners gradually increases (Sedeaud et al., 2014; Weyand, \& Davis, 2005). This fact is in agreement with the research included in this study, where middle- and long-distance runners were $1.81 \pm$ $0.05 \mathrm{~m}$ and $1.72 \pm 0.04 \mathrm{~m}$ tall respectively (Arrese, \& Ostariz, 2006), while ultramarathoners were in the range of $1.75 \pm 6$ to $1.77 \pm 9 \mathrm{~m}$ (Hoffman, 2008). Middle- and long-distance females were $1.69 \pm 5.36 \mathrm{~m}$ (Šolaja et al., 2017) and $161.05 \pm 5.40 \mathrm{~m}$ tall respectively (Yang et al., 2015), whereas ultra-marathoners ranged from $161 \pm 7$ to $1.66 \pm 8 \mathrm{~m}$ (Hoffman, 2008). In the study of Zillmann et al. (2013) it is shown that taller runners are slower than the shorter ones which is not in the agreement with other analyzed research in this study.

Based on the results obtained by different authors (Sedeaud et al., 2014), it can be concluded that body weight is in correlation with the results achieved in running, in both males and females (Weyand, \& Davis, 2005). In the study of Arrese and Ostariz (2006), middle-distance runners' body weight was $69.33 \pm 4.9$ and $52.3 \pm 8.48$ in males and females respectively, long-distance $59.33 \pm 3.34$ and $45.58 \pm 6.82$, while ultramarathoners had body weight of $70.5 \pm 6.4$ to $73.2 \pm 11.5$ and $57.2 \pm 8.2$ to $52.0 \pm 3.5$ (Hoffman, 2008). From the abovementioned, it can be concluded that middle- and longdistance runners are lighter than ultra marathons regardless of the gender. In the study carried out by Knechtle et al. (2009) low weight runners also achieve better results in ultra marathon races. These results indicate that these parameters should not be taken as predictors in the selection and prediction of competition results.

The sum of skin folds is an important result predictor in middle- and long-distance running (Bale et al., 1986; Legaz \& Eston, 2005; Arrese \& Ostariz, 2006) and it can be calculated using defined formulas percentage of body fat (Siri, 1961; Heath, \& Carter, 1967; Jackson \& Pollock, 1985; Ball et al., 2004; Legaz \& Eston, 2005; Lucia et al., 2006). Thus, in the analyzed research in this paper the authors came to the conclusion that low percentage of body fat is a characteristic of Kenyan elite runners $(5.3 \pm 1.6 \%)$ (Kong, \& Heer, 2008). The results of the studies of Arrese and Ostariz (2006) and Legaz and Eston (2005) indicate that lower limbs skin fold thickness is in a positive correlation with racing results in several distances and that this parameter can be a useful predictor in achieving good racing results. Vučetić et al. (2005) and Vučetić et al. (2008) showed that middledistance runners have higher skin fold thickness of upper arms than long-distance runners. On the other hand, skin fold thickness of ultra-marathoners indicates little to moderate association with achieved racing results (Knechtle, \& Rosemann, 2009). The sum of skin fold thickness can be taken as a limitation of this study because in the analyzed studies the calculation of the sum of skin fold thickness differs from study to study, where the number of collection points of the sum of skin folds ranged from 3 to 10 .

The analyzed studies showed that marathoners are specific because of their smaller circumferences in hips and lower limbs (Vučetić et al., 2005), elite Kenyan distance runners because of their slim limbs (Kong, \& Heer, 2008) and well-trained ultra-marathoners a bigger circumference of the upper arm skin fold has a negative correlation with the results achieved in races (Knechtle et al., 2009). Within the Chinese women's marathon team, the circumference of the thigh, the length of the lower extremities and the sum of skin folds were the main indicators of success in the selection of international and national ranks. Female athletes of international rank have thinner thighs and smaller skin fold values (Yang at al., 2015). 


\section{CONCLUSION}

The analysis of the results of previous research shows that morphological characteristics of runners have a significant impact on race performance and achievement of better results in competitions. Measurements of total and partial body composition and anthropometric parameters may be useful for selection, prediction and improving running performance as well as for preventing injuries and health risk assessment. Slim limbs, longer legs, lower total skin fold thickness and lower body fat percentage are some characteristics that can be good predictors of competitive success and a model to be tended during the preparation period of male and female endurance runners.

\section{REFERENCES}

Anderson, T. (1996). Biomechanics and running economy. Sports Medicine, 22 (2), 76-89.

Arrese, A. L., \& Ostáriz, E. S. (2006). Skinfold thicknesses associated with distance running performance in highly trained runners. Journal of Sports Sciences, 24 (1), 69-76.

Bale, P., Bradbury, D., \& Colley, E. (1986). Anthropometric and training variables related to $10 \mathrm{~km}$ running performance. British Journal of Sports Medicine, 20 (4), 170-173.

Ball, S., Swan, P. D., \& Desimone, R. (2004). Comparison of anthropometry to dual energy X-ray absorptiometry: a new prediction equation for women. Research Quarterly for Exercise and Sport, 75 (3), $248-258$

Barandun, U., Knechtle, B., Knechtle, P., Klipstein, A., Rüst, C. A., Rosemann, T., \& Lepers, R. (2012). Running speed during training and percent body fat predict race time in recreational male marathoners. Open Access Journal of Sports Medicine, 3, 51.

Carter, J., L. (1984). 6. Somatotypes of Olympic Athletes from 1948 to 1976. In Physical Structure of Olympic Athletes, pp. 80-109. Karger Publishers.

Claessens, A. L., Hlatky, S., Lefevre, J., \& Holdhaus, H. (1994). The role of anthropometric characteristics in modern pentathlon performance in female athletes. Journal of sports sciences, 12 (4), 391-401.

Davis, D. P., Videen, J. S., Marino, A., Vilke, G. M., Dunford, J. V., Van Camp, S. P., \& Maharam, L. G. (2001). Exercise-associated hyponatremia in marathon runners: a two-year experience. The Journal of Emergency Medicine, 21 (1), 47-57.

Dellagrana, R. A., Guglielmo, L. G., Santos, B. V., Hernandez, S. G., da Silva, S. G., \& de Campos, W. (2015). Physiological, anthropometric, strength, and muscle power characteristics correlates with running performance in young runners. The Journal of Strength \& Conditioning Research, 29 (6), 1584-1591.

Fahey, T. D, Insel, P. M, Roth, W. T. (2001). Fit and well: In Core concept in physical fitness and wellness. 4 th ed. California: Toronto Mayfield Publishing Company.

Gilliat-Wimberly, M., Manore, M. M., Woolf, K., Swan, P. D., \& Carroll, S. S. (2001). Effects of habitual physical activity on the resting metabolic rates and body compositions of women aged 35 to 50 years. Journal of the American Dietetic Association, 101(10), 1181-1188.

Gómez-Molina, J., Ogueta-Alday, A., Camara, J., Stickley, C., Rodríguez-Marroyo, J. A., \& García-López, J. (2017). Predictive Variables of Half-Marathon Performance for Male Runners. Journal of Sports Science and Medicine, 16, 187-194.

Hergenroeder, A. C., \& Klish, W. J. (1990). Body composition in adolescent athletes. Pediatric Clinics of North America, 37 (5), 1057-1083.

Hagan, R. D., Smith, M. G. \& Gettman, L. R. (1981). Marathon performance in relation to maximal aerobic power and training indices. Medicine and Science in Sports and Exercise, 13 (3), 185-189.

Heath, B. H. \& Carter, J. E. (1967). A modified somatotype method. American Journal of Physical Anthropology, 27 (1), 57-74.

Herbst, L., Knechtle, B., Lopez, C. L., Andonie, J. L., Fraire, O. S., Kohler, G., Rüst, C. A. \& Rosemann, T. (2011). Pacing strategy and change in body composition during a Deca Iron triathlon. The Chinese Journal of Physiology, 54 (4), 255-263.

Hoffman, M. D. (2008). Anthropometric characteristics of ultramarathoners. International journal of sports medicine, 29(10), 808-811.

Hoffman, M. D., Lebus, D. K., Ganong, A. C., Casazza, G. A., \& Van Loan, M. (2010). Body Composition of 161-km Ultramarathoners. International Journal of Sports Medicine, 31(2), 106-109. 
Jackson, A. S., \& Pollock, M. L. (1985). Practical assessment of body composition. The Physician and Sportsmedicine, 13(5), 76-90.

Jürimäe, T., \& Jürimäe, J. (2000). Growth, physical activity, and motor development in prepubertal children. Boca Raton, FL: CRC Press.

Karp, J. R. (2007). Training characteristics of qualifiers for the US Olympic Marathon Trials. International Journal of Sports Physiology and Performance, 2 (1), 72-92.

Knechtle, B., Knechtle, P., Schulze, I., \& Kohler, G. (2008). Upper arm circumference is associated with race performance in ultra-endurance runners. British Journal of Sports Medicine, 42 (4), 295-299.

Knechtle, B., Duff, B., Welzel, U., \& Kohler, G. (2009). Body mass and circumference of upper arm are associated with race performance in ultraendurance runners in a multistage race-the Isarrun 2006. Research Quarterly for Exercise and Sport, 80 (2), 262-268.

Knechtle, B., Wirth, A., Knechtle, P., Zimmermann, K., \& Kohler, G. (2009). Personal best marathon performance is associated with performance in a 24-h run and not anthropometry or training volume. British Journal of Sports Medicine, 43 (11), 836-839.

Knechtle, B., \& Rosemann, T. (2009). Skin-fold thickness and race performance in male mountain ultramarathoners. Journal of Human Sport and Exercise, 4(III).

Knechtle, B., Knechtle, P., Barandun, U., \& Rosemann, T. (2011). Anthropometric and training variables related to half-marathon running performance in recreational female runners. The Physician and Sportsmedicine, 39 (2), 158-166.

Kong, P. W., \& De Heer, H. (2008). Anthropometric, gait and strength characteristics of Kenyan distance runners. Journal of Sports Science \& Medicine, 7 (4), 499.

Lee, R. C., Wang, Z., Heo, M., Ross, R., Janssen, I., \& Heymsfield, S. B. (2000). Total-body skeletal muscle mass: development and cross-validation of anthropometric prediction models. The American Journal of Clinical Nutrition, 72(3), 796-803.

Legaz, A., \& Eston, R. (2005). Changes in performance, skinfold thicknesses, and fat patterning after three years of intense athletic conditioning in high level runners. British journal of sports medicine, 39 (11), 851856.

Lepers, R., \& Cattagni, T. (2012). Do older athletes reach limits in their performance during marathon running? Age, 34 (3), 773-781.

Lucia, A., Esteve-Lanao, J., Oliván, J., Gómez-Gallego, F., San Juan, A. F., Santiago, C., \& Foster, C. (2006). Physiological characteristics of the best Eritrean runners-exceptional running economy. Applied Physiology, Nutrition, and Metabolism, 31 (5), 530-540.

Maldonado, S., Mujika, I., \& Padilla, S. (2002). Influence of body mass and height on the energy cost of running in highly trained middle-and long-distance runners. International Journal of Sports Medicine, 23 (04), 268-272.

Marti, B., Abelin, T., \& Minder, C. E. (1988). Relationship of Training and Life-Style to 16-km Running Time of 4000 Joggers. International Journal of Sports Medicine, 9 (2), 85-91.

Mooses, M., Jürimäe, J., Mäestu, J., Mooses, K., Purge, P., \& Jürimäe, T. (2013a). Running economy and body composition between competitive and recreational level distance runners. Acta Physiologica Hungarica, 100 (3), 340-346.

Mooses, M., Jürimäe, J., Mäestu, J., Purge, P., Mooses, K., \& Jürimäe, T. (2013b). Anthropometric and physiological determinants of running performance in middle-and long-distance runners. Kineziologija, 45 (2), 154-162.

Morgan, D. W., Martin, P. E., \& Krahenbuhl, G. S. (1989). Factors affecting running economy. Sports Med, 7 (5), 310-330.

Muth, N. D. (2009). What are the guidelines for percentage of body fat loss. American Council on Exercise $(A C E)$. Ask the Expert Blog. Retrieved at World Wide Web: https://www.acefitness.org/education-andresources/lifestyle/blog/112/what-are-the-guidelines-for-percentage-of-body-fat-loss

Myers, P., \& Steudel, K. (1985). Effect of limb mass and its distribution on the energetic cost of running. Journal of Experimental Biology, 116 (1), 363-373

Nettleton, S. \& Hardey, M. (2006). Running away with health: the urban marathon and the construction of 'charitable bodies'. Health, 10 (4), 441-460.

Onywera, V. O. (2009). East African runners: their genetics, lifestyle and athletic prowess. In Genetics and Sports, pp. 102-109. Karger Publishers.

Pate, R. R., \& O’neill, J. R. (2007). American women in the marathon. Sports Medicine, 37 (4-5), $294-298$.

Ramírez-Vélez, R., Argothy-Bucheli, R., Sánchez-Puccini, M. B., Meneses-Echávez, J. F., \& López-Albán C. A. (2015). Anthropometric and functional characteristics of Colombian elite long-distance runners. Iatreia, 28 (3), 240-247 
Rüst, C. A., Knechtle, B., Knechtle, P., Wirth, A., \& Rosemann, T. (2012). A comparison of anthropometric and training characteristics among recreational male Ironman triathletes and ultra-endurance cyclists. The Chinese Journal of Physiology, 55(2), 114-24.

Saunders, P. U., Pyne, D. B., Telford, R. D., \& Hawley, J. A. (2004). Factors affecting running economy in trained distance runners. Sports Medicine, 34 (7), 465-485.

Sedeaud, A., Marc, A., Schipman, J., Schaal, K., Danial, M., Guillaume, M., Berthelot, G. \& Toussaint, J. F. (2014). Secular trend: morphology and performance. Journal of sports sciences, 32(12), 1146-1154.

Siri, W. E. (1961). Body composition from fluid spaces and density: analysis of methods. Techniques for measuring body composition, 61, 223-44.

Šolaja, A., Milankov, A., Pejakovic, S., \& Stokic, E. (2017). Telesna kompozicija clanova atletske reprezentacije Srbije (Body composition of the Serbian national track and field team). Medicinski Pregled, 70 (3-4), 87-95. In Serbian

Spiriev, B. (1998). IAAF scoring tables of ahletics. Monaco: IAAF.

Tanaka, K., \& Matsuura, Y. (1982). A multivariate analysis of the role of certain anthropometric and physiological attributes in distance running. Annals of Human Biology, 9 (5), 473-482.

Vučetić, V., Babić, V., Šentija, D., \& Nekić, B. (2005). Anthropometric and morphological characteristics of runners. 4th International Scientific Conference on Kinesiology, 7-11 September, Zagreb, 2005.

Vučetić, V. R., Matković, B. \& Šentija, D. (2008). Morphological differences of elite Croatian track-and-field athletes. Collegium antropologicum, 32 (3), 863-868.

Yang, X., G., Wang, Y., Bao, D. P., \& Hu, Y. (2015). Anthropometric Characteristics of Chinese Professional Female Marathoners and Predicted Variables for Their Personal Bests. Collegium Antropologicum, 39(4), 899-905.

Zillmann, T., Knechtle, B., Rüst, C. A., Knechtle, P., Rosemann, T., \& Lepers, R. (2013). Comparison of training and anthropometric characteristics between recreational male half-marathoners and marathoners. The Chinese Journal of Physiology, 56 (3), 138-146.

Williams, C., \& Nute, M. L. (1983). Some physiological demands of a half-marathon race on recreational runners. British journal of sports medicine, 17(3), 152-161.

\section{UTICAJ MORFOLOŠKIH KARAKTERISTIKA NA PERFORMANS TRČANJA DUGOPRUGAŠA}

Trčanje je popularna forma fizičke aktivnosti i može biti realizovana kroz više različitih distanci. Morfološke karakteristike, kao što su debljina kožnog nabora, obim butina i njihova dužina, telesna masa i procenat telesnih masti imaju uticaj na trčanje na duge staze. Cilj ovog sistematskog preglednog rada je prikupljanje i analiza istraživanja koji su se bavili uticajem morfoloških karakteristika na performansu trčanja kod dugoprugaša. Na osnovu pretraženih elektronskih baza i postavljenih kriterijuma, 20 istraivanja je uključeno u analizu. Visok nivo statističke značajnosti kao predikora imaju dužina ekstremiteta, kao i zbir kožnih nabora. Rezultati analiziranih istraživanja pokazuju da su tanki udovi, duže noge, manji sveukupni zbir kožnih nabora $i$ niži procenat telesnih masti neki od karakteristika koji mogu biti dobri predilktori takmičarskog uspeha i model kojem treba težiti tokom pripremnog perioda kod žena i muškaraca dugoprugaša.

Ključne reči: antropometrija, telesna kompozicija, izdržljivost, trčanje. 